\title{
Organizational and managerial measures to identify and document crimes of illegal coal mining (by the example of Kuzbass)
}

\author{
Yury Volgin ${ }^{1, *}$, Olga Safargalieva ${ }^{1}$, and Oleg Sergeev ${ }^{1}$ \\ ${ }^{1}$ Kemerovo State University, 650000, 6 Krasnaya st., Kemerovo, Russia
}

\begin{abstract}
Based on the analysis of the operational situation in the Kemerovo region, the article formulates recommendations on the content of organizational and managerial measures aimed at ensuring the detection and documentation of crimes in the field of illegal coal mining. Considering the operational situation, the crimes in the field of illegal coal mining committed on the territory of Kuzbass were characterized. A description of the organizational structure and effectiveness of activities directed to fighting against crimes in the field of illegal coal mining realized by operational units of economic safety and anti-corruption of the Chief Administration of the Ministry of Internal Affairs of Russia in the Kemerovo region was made. The proposed organizational and management measures include: measures aimed at changing the organizational structure of the operational units of economic security and anti-corruption of the Chief Administration of the Ministry of Internal Affairs of Russia in the Kemerovo region. Measures to increase the efficiency of operational services for coal mining enterprises and territories in which illegal coal mining are considered as well. The recommendations for changing the organizational structure are based on the choice of the type of operational service. Measures aimed at improving the efficiency of operational services contain such recommendations as: the organization of interaction with various state and law enforcement agencies; the choice and change of the operational service regime, as well as the formation of open sources of operational search information.
\end{abstract}

\section{Introduction}

In the general list of problems that have a negative impact on the development of the Kuzbass economy, illegal coal mining should be highlighted. According to data received from employees of the Chief Administration of the Ministry of Internal Affairs of the Russian Federation in the Kemerovo region (hereinafter - CA MIA RF in $\mathrm{Kr}$ ), for a year the damage from illegal coal mining amounts to several hundred million rubles. Open publications suggest that the size of the illegal coal business is comparable to the drug trade. So, annually through offshore zones and affiliated persons more than 3 billion rubles are with-

*Corresponding author: volgin384@mail.ru 
drawn [1]. The experts characterize the negative consequences of illegal coal mining as follows.

Firstly, this is direct damage to the state, which does not receive a fee for licensing subsoil use and taxes [2].

Secondly, illegal mining, as a rule, is carried out in already developed places, while doing harm to areas with coal reserves.

Thirdly, illegal coal mining causes enormous environmental damage in the region [3] and the unique natural complex of Kuzbass.

Fourth, often illegally mined coal is supplied to other regions of Russia and abroad. The poor quality of illegally extracted fuel, in the end, affects the image of the Kemerovo region as a coal supplier.

Fifthly, the so-called "black diggers", when conducting mining operations, destroy or pollute communications, damage buildings, land plots, and forests [4], water bodies [5], etc.

Sixthly, people, illegally mining coal, neglect the rules of mining and safety, creating a real threat to the life and health of people [6-7].

In these circumstances, it is necessary to oppose illegal coal mining by law enforcement agencies [8].

The noted circumstances determine the need to consider organizational and managerial measures, which are the basis for the detection and documentation of crimes related to illegal coal mining, as part of a package of measures to fight illegal coal mining.

\section{Materials and methods}

The development of organizational and managerial measures to create conditions for the effective activity of operational units of economic security and anti-corruption to identify and document crimes related to illegal coal mining requires an initial assessment and analysis of the operational situation, in particular, its following elements:

- the characteristics of crimes in the field of illegal coal mining;

- a description of the operational units of economic security and anti-corruption of CA MIA $\mathrm{RF}$ in $\mathrm{Kr}$ and the effectiveness of their activities in fighting crimes in the field of illegal coal mining.

According to data obtained from the Information Center of CA MIA RF in Kr, from 4 (in 2015) to 34 (in 2012) crimes in the field of illegal coal mining are detected annually. Describing the places where these crimes were committed it should be pointed out that their main share $(83.56 \%)$ was committed in the south of the Kemerovo region - in Novokuznetsk, Prokopyevsky, Belovsky districts, the cities of Kiselevsk, Osinniki and others.

The reasons that the indicated crime areas are the main places for committing crimes in the field of illegal coal mining are quite objective.

Firstly, these are territories where coal seams are located close to the surface of the earth and therefore their development does not require additional engineering solutions. In certain areas, coal seams go to the surface to a depth of 0.5 meters. Availability and minimum costs for subsequent profit making are the basis for the penetration of crime in this area of activity.

As the next reason, it is necessary to point out that in this area there are a large number of abandoned territories and closed coal mining enterprises. When coal mining enterprises having been closed, specialists who had the necessary special knowledge and had information about the location of easily accessible coal deposits became unemployed [1].

Crimes are committed by persistent organized criminal groups having relations in state authorities, including in law enforcement and supervisory authorities, as well as by individual citizens who have mining skills and special equipment. 
Organized criminal groups using "cover" documents often commit crimes in the field of illegal coal mining. Organizations engaged in land reclamation on the territory of liquidated coal mining enterprises, in fact, are producing and selling coal on an industrial scale.

Recently, as operational officers note, the illegal production of coal has acquired the character of short-term "raids". In such cases, coal is mined mainly at night for 2-3 days, after which the attackers change the place of extraction.

The next element of the operational environment is the characterization of the operational units of economic security and anti-corruption of CA MIA RF in $\mathrm{Kr}$ and the effectiveness of their activities in the crimes in the field of illegal coal mining.

Direct identifying, documenting, disclosing, and operatively searching the investigation of crimes in the field of illegal coal mining is a function of the crime control department in priority sectors of the economy. It should be noted that in the period from 2011 to 2014 there was a specialized department to combat theft in the coal industry in the structure of the Department of Economic Security and Anti-Corruption of CA MIA RF in Kr.

The performance of this structural unit is demonstrated by the following data. According to the information of CA MIA RF, Kuzbass took the first place among the subjects of the Siberian Federal District in the number of crimes detected in 2012 by law enforcement agencies in the field of the fuel and energy complex. During this period, employees of this department revealed and documented crimes, compared with the previous period, in the field of the fuel and energy complex more than 1.8 times, including the coal industry in 1.9 times.

In addition to the Office of Economic Security and Anti-Corruption of CA MIA RF in $\mathrm{Kr}$, the departments of economic security and anti-corruption of territorial internal affairs agencies also identify and document crimes in the field of illegal coal mining.

Describing the activities of the operational units of economic security and anticorruption in identifying, documenting, combating and solving crimes in the field of illegal coal mining it should be noted that they implemented a number of organizational measures, in particular:

- the basic directions of the illegal activities of organized criminal groups in the field of the fuel and energy complex have been established;

- the database of persons and organized criminal groups involved in the organization of illegal coal mining and theft in the coal industry has been formed;

- the list-register of heat and power facilities and housing and communal services in state and municipal ownership has been formed;

- for effective counteraction to criminal acts, contacts with the security services of enterprises and holdings were established.

In addition to the security services of coal mining enterprises, interaction with the following state bodies has been organized:

- Office of the Federal Security Service of Russia in the Kemerovo Region;

- Kemerovo customs;

- Siberian Department of the Federal Service for Ecological, Technical and Nuclear Supervision;

- Office of the Federal Service for Supervision of Natural Resources in the Kemerovo region;

- Kemerovo inter-district prosecutor's office for supervision of the implementation of laws in the coal mining industry [9] and others.

The operational units of the Department of Economic Security and Anti-Corruption of CA MIA RF in $\mathrm{Kr}$ are constantly conducting activities aimed at identifying and combating crimes related to the illegal extraction, transportation and trafficking of coal.

Operational officers check the areas where the coal was produced, or illegal coal mining may be carried out. In the process of such verification, both land and air types of special 
vehicles are used to inspect the territories. However, at present, aviation is practically not used to control the territories and objects of the coal industry. The objective reason for this state of affairs is the allocation as an independent structure of the Office of the Federal Service of the National Guard Troops of the Russian Federation in the Kemerovo Region and the transfer to its subordination of a special operations detachment.

To control territories, the operational units of economic security and anti-corruption also use unmanned aerial vehicles, the capabilities of which are described in the literature [10]. This helps operational officers to study the suspects' work patterns, including the establishment of stolen coal shipping points. However, unmanned aerial vehicles are also the means of an aviation unit of the Office of the Federal Service of the National Guard Troops of the Russian Federation in the Kemerovo Region.

\section{Results and discussion}

The analysis of the effectiveness of the operational units of economic security and anticorruption of CA MIA RF in $\mathrm{Kr}$ allows concluding that additional measures of an organizational and managerial nature are necessary.

We believe that in order to identify, combat and document crimes in the field of illegal coal mining, regardless of the criminal legal qualification [11], it is necessary to create a specialized department to combat theft in the coal industry. This department should be a structural unit of the Office of Economic Security and Anti-Corruption of the Chief Administration of the Ministry of Internal Affairs of the Russian Federation in the Kemerovo region. Staffing issues should be resolved according to the general rule for the formation of operational units of internal affairs bodies.

Other organizational and managerial measures involve the creation of the conditions necessary for the efficient work of the operational units of economic security and anticorruption of the internal affairs bodies. These measures include:

- ensuring operational and tactical readiness of the operational units of economic security and anti-corruption of internal affairs bodies to respond to signals about crimes committed in the field of illegal coal mining;

- organizing interaction between operational units of economic security and anti-corruption of internal affairs bodies with other entities;

- providing control over the activities of operational units of economic security and anticorruption of the internal affairs bodies;

- providing operational control over coal mining facilities and territories in which illegal coal mining is carried out or may be carried out.

Assessing measures on ensuring operational tactical readiness described in the scientific literature on the theory of operational search activity, we believe that the following items should be included in the number of measures implemented:

- the creation of reliable channels of information on having been committed and being committed crimes in the field of illegal coal mining;

- ensuring the uninterrupted use of operational search activity;

- ensuring the possibility of maneuvering with the available forces and means of the operational units of economic security and anti-corruption of the internal affairs bodies;

- the development of standard options for actions when receiving signals of crimes in the field of illegal coal mining.

Among the entities with which it is necessary to organize cooperation with the operational units of economic security and anti-corruption in identifying and documenting crimes in the field of illegal coal mining, the following items should be highlighted:

- other (not being operational units of economic security and anti-corruption) operational units of internal affairs bodies; 
- investigative units of internal affairs bodies;

- units of internal affairs bodies that are not operational;

- other law enforcement agencies;

- Office of the Federal Agency for Subsoil Use in the Kemerovo Region;

- Office of the Federal Service for Supervision of Natural Resources in the Kemerovo region;

- Department of coal industry and energy of the Administration of the Kemerovo region;

- Interregional Directorate of the Federal Service for Financial Monitoring in the Siberian Federal District;

- Office of the Federal Antimonopoly Service in the Kemerovo Region;

- Kemerovo Customs;

- security services of coal mining enterprises.

Among the main tasks of such interaction, the following should be noted:

- ensuring urgent investigative actions and operational search measures for criminal cases for crimes in the field of illegal coal mining;

- full, comprehensive and objective documentation of crimes in the field of illegal coal mining;

- timely disclosure and prosecution of persons who committed a crime in the field of illegal coal mining;

- the implementation of measures aimed at redressing material damage caused by a crime in the field of illegal coal mining.

The next organizational and managerial measure ensuring the activities of the operational units of economic security and anti-corruption in identifying and documenting crimes in the field of illegal coal mining is the organization of control, which is regulated by law [12].

The main objectives of control are:

- timely prevention of violations of the law and the disclosure of deficiencies in the process of identifying and solving crimes in the field of illegal coal mining;

- identifying the conformity of the activities of the operational units of economic security and anti-corruption with the requirements of the legislation of the Russian Federation and departmental regulatory acts;

- ensuring the conspiracy and security of persons cooperating with the operational units of economic security and anti-corruption on a confidential basis;

- ensuring the unity of decisions and their implementation.

The forms of monitoring the activities of operational units of economic security and anti-corruption in identifying and documenting crimes in the field of illegal coal mining should include familiarizing the head with the affairs of operational activity, the unit's work and its particular employees; continuous study of operational relevant information and public opinion; hearing separate employees during operational meetings, etc.

Separately, when solving organizational and managerial issues to ensure the activities of operational units of economic security and anti-corruption in identifying and documenting crimes in the field of illegal coal mining, in our opinion, we should consider the organization of operational services in coal-mining enterprises and territories in which illegal coal mining may occur.

The analysis of operational search activities and operational tasks allows identifying the following in order to solve the problems of detecting and investigating crimes in the field of illegal coal mining:

1. Identification and verification of persons contemplating, preparing and committing crimes in the field of illegal coal mining.

2. Establishment and accounting of objects of operational interest, determination of methods for their maintenance. 
3. Providing operational monitoring of the serviced territory, objects and persons who are on criminal records.

4. The identification and verification of previously unknown persons and facts of operational interest in solving the problems of identifying and documenting crimes in the field of illegal coal mining, their registration, the implementation of operational search control.

5. Establishment of the causes and conditions of specific crimes in the field of illegal coal mining committed at a serviced facility, taking measures to eliminate them.

In their activities, the operational units of economic security and anti-corruption, depending on various factors, use various types of operational services. In the theory of operational search activity, there are object-industry services; linear-object service; zonal (territorial) service; cross-industry services; end-to-end operational service.

In solving problems of detecting and investigating crimes in the field of illegal coal mining, it seems to be appropriate to use a linear-object type (principle) of servicing coal mining enterprises and territories where illegal coal mining may be carried out.

Forming the elements of the operational service system for the identification, prevention and documentation of crimes in the field of illegal mining of coal, we consider the following to be appropriate:

- to determine the list of coal mining enterprises and assign operational employees to them;

- to study the operational situation at each of the coal mining enterprises and determine the operational service regime for them;

- to carry out the selection and placement of confidential information sources at coal mining facilities;

- to organize the interaction with the previously indicated entities;

- to ensure the conduct of operational activities;

- to ensure the formation and use of legal information systems for operational search purposes.

In the theory and practice of operational-investigative activity, three types of operational service modes have been developed enhanced, normal, and light.

The definition of the operational service mode should relate to the competence of the head of the anti-theft department in the coal industry and should be determined by the nature of the operational situation.

It should be borne in mind that in the process of activity of employees of the economic security and anti-corruption divisions, the operational service mode may be changed.

Information support for the activities of operational employees of the department to combat theft in the coal industry involves the functioning of information sources. Information about the state of the operational situation comes from two types of sources: operational and open.

Carrying out the initial analysis of the operational situation at the serviced object, the operational employee must determine the most criminogenic areas and provide them with cover by persons providing confidential assistance. It is necessary to involve in confidential cooperation such persons who, by virtue of their official position, professional capabilities, can provide information on the production and economic activities of the facility (several sites), persons who may be subject to operational monitoring, etc.

Sources of open information on the state of the operational situation are the administration of the serviced objects, state regulatory authorities (in the process of inspections, various violations and abuses are often identified that allow creating an objective picture of the state of the operational situation at the serviced object), law enforcement agencies, mass media (information contained in analytical reviews, articles, feuilletons, materials of journalistic investigations contains information about the state of the operational situation), coal mining services, labor staff and public organizations, citizens. 
A very important element of operational support is the interaction of operational employees of the anti-theft department in the coal industry with various individuals, bodies and organizations.

It is advisable to use the following forms of such interaction: joint planning, fulfillment of instructions and tasks (search tasks, individual orders of the investigator, tasks for carrying out technical activities), information exchange (orientation, memoranda, messages, for example, to places of imprisonment and vice versa), carrying out joint events (operations on detention, raids, etc.).

For the accumulation, storage, analysis of information about the state of the operational situation at the serviced object, cases of operational accounting should be used. The amount of information, types of documents along the lines of work are determined taking into account the specifics of the tasks performed and the facilities being serviced.

\section{Conclusion}

In order to increase the effectiveness of the fight against illegal coal mining in Kuzbass, the following group of organizational and managerial measures is needed to create the conditions for work of operational units of economic security and anti-corruption of the Chief Administration of the Ministry of Internal Affairs of the Russian Federation in the Kemerovo region.

1. In order to identify, investigate and document crimes in the field of illegal coal mining, it is necessary to create a department to combat theft in the coal industry in the structure of the Office of Economic Security and Anti-Corruption of the Chief Administration of the Ministry of Internal Affairs of the Russian Federation in the Kemerovo region. The issues of the staffing of the department should be resolved according to the general rule for the formation of operational units of internal affairs bodies.

2. In the process of identifying and documenting crimes in the field of illegal coal mining, it is advisable:

- to ensure the interaction of the operational unit to combat theft in the coal industry with units of the internal affairs bodies, other law enforcement agencies, and the administration of the Federal Subsoil Use Agency in the Kemerovo Region; Office of the Federal Service for Supervision of Natural Resources in the Kemerovo region; Department of Coal Industry and Energy of the Administration of the Kemerovo Region; Interregional Directorate of the Federal Service for Financial Monitoring in the Siberian Federal District; Department of the Federal Anti-Monopoly Service in the Kemerovo Region; Kemerovo Customs; coal mining security services;

- to use, for the control of territories and objects, means of an aviation unit of the Office of the Federal Service of the National Guard Troops of the Russian Federation in the Kemerovo Region;

- to use a linear-object type of service for coal mining enterprises and territories in which illegal coal mining may be carried out; the definition of the operational service mode should relate to the competence of the head of the anti-theft department in the coal industry and be determined by the nature of the operational situation;

- to ensure the flow of operational information from open and tacit sources.

\section{References}

1. R. Drapezo, V. Shelestukov, E3S Web Conf., 105, 02016 (2019)

2. S. Suyoto, D.A. Hartanto, Jurnal Dinamika Hukum, 18:2, 200-207 (2018) 
3. S. Boadi, C. A. Nsor, O. O. Antobre, E. Acquah, Journal of Sustainable Mining, 15, $115-$ 119 (2016)

4. İ. Kervankiran, M.G. Dziwornu, K. Temurcin, Zeitschrift für die Welt der Türken, 8:3, 173-191 (2016)

5. Mwazvita, T.B. Dalu, R.J. Wasserman, T. Dalu, South African Journal of Science, 113:11-12, 2 (2017)

6. M. Agienko, A. Naumov, I. Gaag, Y. Volgin, E3S Web Conf., 41, 04046 (2018)

7. O. Safargalieva1, O. Sergeev, Y. Volgin1, M. Agienko, E3S Web Conf., 105, 02012 (2019)

8. F. U. Puluhulawa, Journal of Dinamika Hukum, 15:3, 273-277 (2015)

9. 2. V. Shelestukov, V. Erin, G. Pavlov, E3S Web Conf., 41, 02029 (2018)

10. S. Penmetsa, F. Minhuj, A. Singh, S.N. Omkar, Electronic Letters on Computer Vision and Image Analysis, 13:1, 18-32 (2014)

11. The Code of Criminal Procedure of the Russian Federation of December 18, 2001 (as amended and supplemented) (Collection of the legislation of the Russian Federation, Moscow, 2001)

12. On operative-search activity: federal law of August 12, 1995 No. 144-FZ (with subsequent amendments and additions) (Collection of the legislation of the Russian Federation, Moscow, 1996) 